\title{
The Effects of Toluene Administration in Rabbits Kidneys Tissues
}

\author{
Wasfi Dhahir Abid Ali $^{1 *}$, Luay abdulwahid shihab ${ }^{2}$, Abdulkareem Salman Khudhair ${ }^{3}$
}

${ }_{1}^{1}$ Department of Basic Sciences College of Nursing -University of Iraq -Ph.D in Physiology
${ }^{2}$ Department of basic Sciences College of Nursing -University of Iraq master in Computer Science
${ }^{3}$ Department of Basics of Nursing College of Nursing -University of Iraq Master in Adult Nursing

DOI: $10.36347 /$ sjahss.2020.v08i02.001

| Received: 04.02.2020 | Accepted: 11.02.2020 | Published: 14.02.2020

*Corresponding author: Wasfi Dhahir Abid Ali

\section{Abstract}

The present histological pathological study conducted in nursing college -university of Basrah - Republic of Iraq, Ten adult male rabbits given toluene $0.3 \mathrm{ml}$ of toluene $(97 \%) / \mathrm{Kg} \mathrm{B.W}$ subcutaneously and other ten used as control group revised normal saline ( $0.9 \% \mathrm{Na} C L$ ) for six weeks, the results showed that toluene caused sever changes in kidney tissue specially the main functional renal units , the tubules epithelia and glomeruli as well as . jaxtaglumerule cells.

Keywords: Toluene, lung, kidney, rabbits.

Copyright @ 2020: This is an open-access article distributed under the terms of the Creative Commons Attribution license which permits unrestricted use, distribution, and reproduction in any medium for non-commercial use (NonCommercial, or CC-BY-NC) provided the original author and source are credited.

\section{INTRODUCTION}

Toluene is a type of volatile, colorless and commonly used aromatic hydrocarbon used as paint solvent, a mixture of gasoline, nail polish, and as a solvent in the printing business. Toluene enters the body through 3 pathways, inhalation, ingestion and skin contact. Petrol without lead contains amounts of aromatic hydrocarbons among aromatic compounds, benzene, toluene, and xylenes (BTX) are the most dangerous elements of petrol [1, 2, 3].

The risk of acute or chronic toxicity in humans exists during production, distribution, and use of petrol. Symptoms that may arise are fatigue, easy drowsiness, headaches, and nausea [4]. Chemically toluene is a hydrocarbon that is rapidly absorbed through the respiratory and gastrointestinal tracts and, to a lesser extent, through the skin [5]. In addition, smokers are exposed to $80-100 \mu \mathrm{g}$ of toluene within a cigarette. Furthermore, top products containing toluene are paints, paint thinners, varnish, shellac, rust preventers, glues, solvent based cleaners, and some cleaning products. It is also used as a solvent in cosmetic products and commonly in benzyl chloride, benzoic acid, phenol cresol, vinyl toluene, TNT, and toluene diisocyanate production. Baydas et al. [6]. Hence, many people are exposed to toluene, also via human and animal drinking waters, foods, air, and various consumer goods [7]. Alkylbenzenes such as toluene, xylene, ethylbenzene, styrene and cumene are toxicologically important since they are produced, used or disposed of in the largest quantities and therefore might pose significant and potential health risks to man and the environment. Toluene (toluol; methylbenzene; phenylmethane), an aromatic hydrocarbon similar to benzene, is used mainly (92\%) as a component of gasoline. Pariselli et al. [8] found that exposure to a mixture of toluene and benzene in air led to an increase in the cytotoxic effect and DNA damage without any further repair, but did not induce any changes in the glutathione redox status. High levels of Toluene can be found in the liver and brain in people with death from toluene inhalation [9].

Sulaiman et al. [10] findings suggest AGP's protective function against TDI-induced airway epithelial barrier dysfunction and oxidative lung damage possibly through the upregulation of adherence junction proteins and the activation of $\mathrm{p} 38 / \mathrm{Nrf} 2$ signaling. A patient diagnosed with an acute exacerbation of chronic obstructive pulmonary disease complicated with pulmonary hypertension. Heavy smoking from a young age and exposure to toluene was the suspected causes of the patient's severe pulmonary emphysema [11].

\section{MATERIALS AND METHODS}

Ten adult male rabbits, weighing 950- $1200 \mathrm{~g}$, were allotted in two experimental groups. The animals were purchased from a local market and housed in individual cages $(360 \cdot 200 \cdot 190 \mathrm{~mm})$ the animal were available ad libitum Food and tap water for both groups 
, the first group take normal saline $0.9 \% \mathrm{Na}$ CL while the second group received $0.3 \mathrm{ml}$ of toluene $(97 \%) / \mathrm{Kg}$ B.W subcutaneously daily for 6 weeks. At the end of the experiment anesthetized by intramuscular injection of mixture xylazine2\% (Alfasan- Holland) and ketamine $10 \%$ (Kepro -Holland). Animals scarified and studied organ (lung and kidneys) were isolated in $10 \%$ formalin for path- histological examination.

\section{RESULTS AND DISCUSSION}

The present study showed that administration of toluene subcutaneously caused many changes in rabbits kidney tissues .under light microscope cross section in kidney showing kidney with swilling of jaxtaglumerule cells compared with the control figure (2), as well as caused sloughing of epithelial lining tissue of distal convoluted tubule, figure (3).
In addition rabbits kidney showing kidney degeneration of lining epithelial cells of proximal convoluted tubule, figure (4) and dilation of space of glomeruli, figure (5). Hydrocarbon exposure has been shown to play an important role in the development of renal dysfunction in several occupational settings. Distal renal tubular acidosis is a common finding in toluene abusers and has even been found in infants born to mothers who abused toluene [12] .exposure to benzene and alkyl benzene has been associated with kidney and liver injury and kidney cancer [13, 14]. Brautbar and Williams [15] pointed that chronic exposure to low concentrations of solvents in occupational settings may cause damage to the kidney and liver of exposed individuals which is difficult to identify. Maryam, et al. [16, 17] Concluded on their study demonstrated that toluene damages kidney tissue and is a nephrotoxic substance.

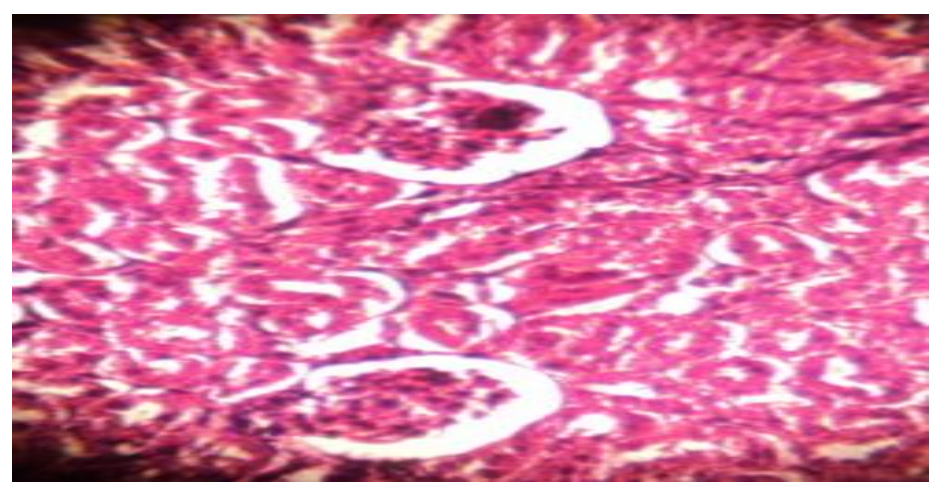

Fig-1: Cross section of Kidney of control rabbit showing normal renal structure; normal size of glomeruli, normal lining cuboidal tissue of renal tubules .H\&E) stain.100X

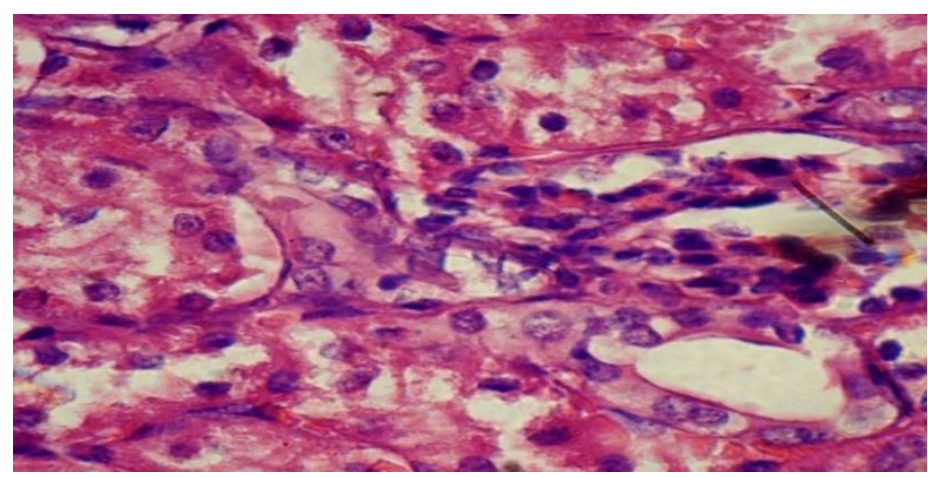

Fig-2: Cross section of rabbit's kidney showing kidney with Swilling of jaxtaglumerule cells. (H\&E) stain. 100X

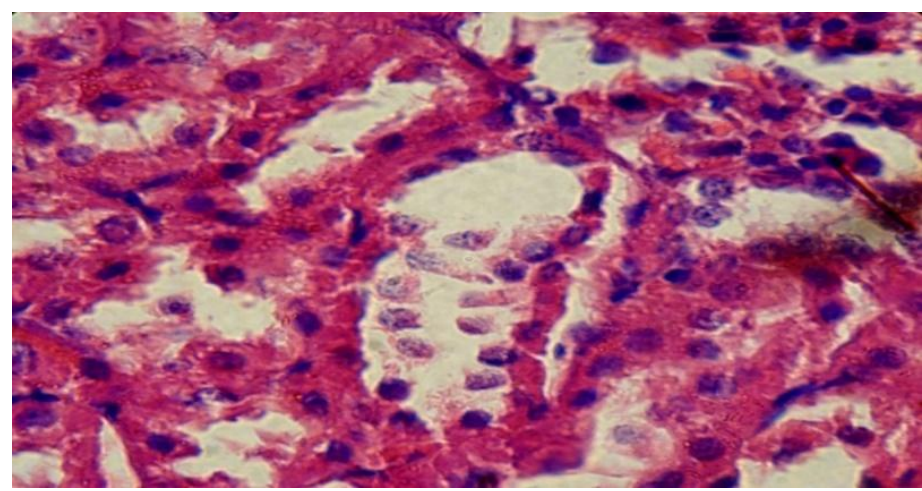

Fig-3: Cross section of rabbit's kidney showing kidney slough of epithelial line [ining tissue of distal convoluted tubule, .H\&E) stain.100X 


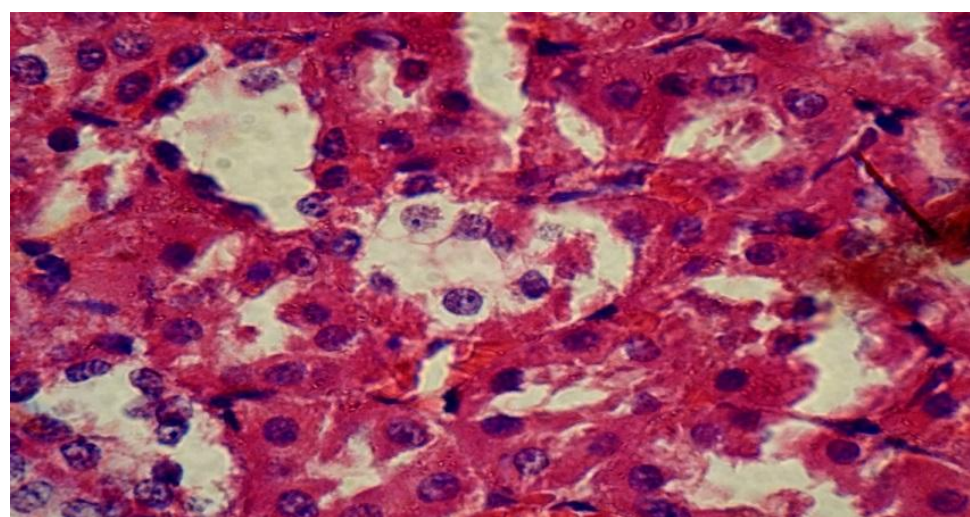

Fig-4: Cross section of rabbit's kidney showing kidney degeneration of lining epithelial cells of proximal convoluted tubule, .H\&E) stain .100X.

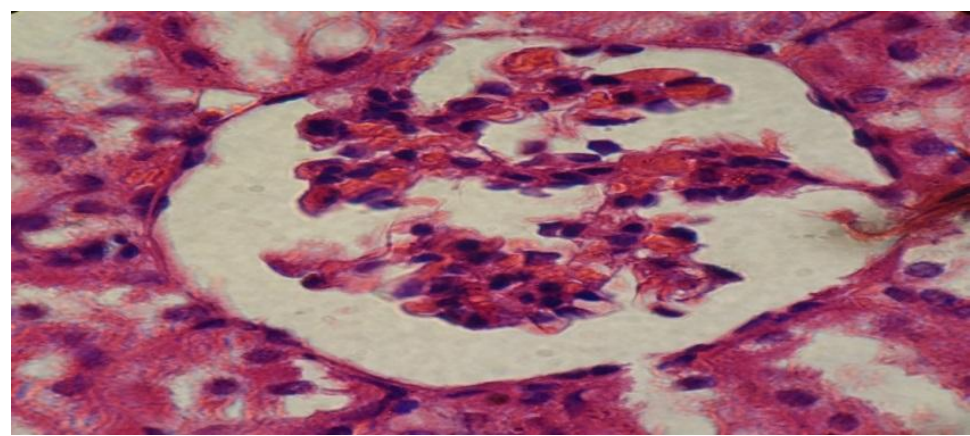

Fig-5: Cross section of rabbits kidney showing kidney dilation of space of glomeruli,(H\&E) stain. 100X

\section{ACKNOWLEDGEMENT}

My sincere gratefulness and thanks to. Prof. Dr. Ali Abid Allateef College of Education for pure sciences - university of Basrah.

\section{CONCLUSION}

The study conclude that $\mathrm{S} / \mathrm{C}$ administration of toluene induce a negative changes in rabbits kidney tissues.

\section{REFERENCES}

1. Ahmed HH, Metwally FM, Rashad HM. Toxicity of solvents exposure on the neuroendocrine system in rats: role of amino acids supplementation. Toxicity of Solvents, Report and Opinion. 2009;1(4):66-83.

2. Perigo JF, Prado C. Evolution of occupational exposure to environmental levels of aromatic hydrocarbons in service stations. Ann Occup Hyg. 2005; 49:233-240.

3. Adami G, Larese F, Venier M, Barbieri P, LoCoco F. Reisenhofer E. Penetration of benzene, toluene and xylenes contained in gasoline's through human abdominal skin in vitro. Toxicol In Vitro, 2006; 20:1321-1330.

4. ATSDR. Toxicological Profile for Toluene [Internet]. United States: US Department. Retrieved August. 2015; 20, 2018, from https://www.atsdr.cdc.gov/ toxprofiles/tp56.pdf.

5. Fagot-Campagna, A., Narayan, K. V., \& Imperatore, G. (2001). Type 2 diabetes in children: exemplifies the growing problem of chronic diseases.

6. Baydas G, Gursu MF, Yilmaz S. Daily rhythm of glutathione peroxidase activity, lipid peroxidation and glutathione levels in tissues of pinealectomized rats. Neuroscience Letters, 2002; 323(3):195-198

7. Agency for Toxic Substances and Disease Registry (ATSDR). CSEM Toluene Toxicity: Environmental Medicine Case Study. Atlanta, Ga, USA, 2007

8. Agency for Toxic Substances and Disease Registry. Toxicological Profile for Toluene. U.S. Public Health Service (in collaboration with U.S. Environmental Protection Agency), Atlanta, GA, 1989.

9. Eisenberg DP. Neurotoxicity and mechanism of toluene abuse. Einstein QJ Biol Med. 2003; 19, 150-159.

10. Sulaiman I, Tan K, Mohtarrudin N, Lim JCW and Stanslas J. Andrographolide prevented toluene diisocyanate-induced occupational asthma and aberrant airway Ecadherin distribution via p38 MAPK-dependent Nrf2 induction. Pulm Pharmacol Ther. 2018 Dec; 53:39-51.

11. Kobayashi K, Suzuki M, Yamamoto S, Ueno K, Miyawaki E, Takazawa I, Shiozawa A, Sato T, Hojo M, Sugiyama. HEarly-onset, Severe Chronic Obstructive Pulmonary Disease with Pulmonary Hypertension that was Likely Induced by Toluene Exposure. Intern Med. $2017 \quad$ Sep 1;56(17):2329-2334 
12. Lindemann R. Congenital renal tubular dysfunction associated with maternal sniffing of organic solvents. Acta paediatrica scandinavica. 1991; 80: 882-884

13. Brautbar N, Wu MP, Gabel E, Regev L. Occupational kidney cancer exposure to industrial solvents. Ann N Y Acad Sci.2006; 1076:753-764.

14. Henderson RF. Aromatic hydrocarbons benzene and other alkylbenzenes. In: Bingham E., Cohrssen B., Powell C.H., editors. 5th ed. Vol. 4. John Wiley \& Sons; Mississauga (ON), 2001; 231-260. (Patty's toxicology).
15. Brautbar and Williams. II Industrial solvents and liver toxicity a review study. Int J Hyg Environ Health.2002; 205:479-491.

16. Maryam Afravy, Kambiz Angali, Ali Khodadadi, and Massumeh Ahmadizadeh The protective effect of Buffalo's milk against toluene inducednephrotoxicity in rats, J Nephropathol. 2017; 6(3): 174-179.

17. Pariselli F, SaccoG J, Ponti and D Ponti. Effects of toluene and benzene air mixtures on human lung cells (A549). Experimental and Toxicologic Pathology. 2009; 61(4), 81-386. 